\title{
Effects and action mechanism of Diospyros kaki on the differentiation of human leukemia HL-60 cells
}

\author{
SEUNG HYUN KIM ${ }^{1}$, SEUNG SIK CHO ${ }^{2}$, JAYA RAM SIMKHADA ${ }^{2}$, SUNG JU PARK ${ }^{2}$, \\ HYO JEONG LEE ${ }^{3}$, TAE SUNG KIM ${ }^{1}$ and JIN CHEOL YOO ${ }^{2}$
}

\author{
${ }^{1}$ School of Life Sciences and Biotechnology, Korea University, Seoul 136-701; ${ }^{2}$ Department of Pharmacy, \\ College of Pharmacy, Chosun University, Gwangju 501-759; ${ }^{3}$ Department of Complementary and Alternative Therapy, \\ College of Management, Commerce and Social Welfare, Gwangju University, Gwangju 503-703, Korea
}

Received April 8, 2009; Accepted July 3, 2009

DOI: 10.3892/or_00000609

\begin{abstract}
Diospyros kaki Thunb. (Ebenaceae) is widely distributed in North-East Asian countries. Almost all parts of this plant have been traditionally used as medicine. Human promyelocytic leukemia cells differentiate into monocytes or granulocytes when treated with 1,25-dihydroxyvitamin $\mathrm{D}_{3}$ $\left[1,25-(\mathrm{OH})_{2} \mathrm{D}_{3}\right]$ or all-trans retinoic acid (ATRA). Combination of low doses of ATRA or 1,25-dihydroxyvitamin $\mathrm{D}_{3}$ that do not induce toxicity with another drug is a useful strategy for acute promyelocytic leukemia therapy. Our main aim was to investigate the effect of an acetone extract of $D$. kaki leaves (KV-1) on HL-60 cell differentiation in combination of ATRA or 1,25-dihydroxyvitamin $\mathrm{D}_{3}$. Treatment of HL-60 cells with zero to $100 \mu \mathrm{g} / \mathrm{ml}$ of $\mathrm{KV}-1$ for $72 \mathrm{~h}$ induced a small increase in cell differentiation. Surprisingly, a synergistic induction of differentiation was observed when the HL-60 cells were treated with ATRA or $1,25-(\mathrm{OH})_{2} \mathrm{D}_{3}$ and the extract. The inhibitors of protein kinase $\mathrm{C}(\mathrm{PKC})$ ( $\alpha$ and $\mathrm{BI}$ ) and extracellular signalregulated kinase (ERK), but not of phosphoinositide 3-kinase (PI3-K) and c-Jun N-terminal kinase (JNK) inhibited the HL-60 differentiation induced by the extract in combination of ATRA or 1,25-(OH) ${ }_{2} \mathrm{D}_{3}$, suggesting that PKC and ERK were involved in the cell differentiation enhancement by the extract. The results indicate that the acetone extract of $D$. kaki leaves has the ability to enhance HL-60 cell differentiation and suggest that it may be useful in acute promyelocytic leukemia therapy.
\end{abstract}

\section{Introduction}

Diospyros kaki Thunb. (Ebenaceae), commonly called persimmon, is widely distributed throughout Korea, Japan,

Correspondence to: Dr Jin Cheol Yoo, Department of Pharmacy, College of Pharmacy, Chosun University, Gwangju 501-759, Korea E-mail: jcyu@chosun.ac.kr

Key words: cell differentiation, Diospyros kaki, HL-60 cells, 1,25-dihydroxyvitamin $\mathrm{D}_{3}$, all-trans retinoic acid, protein kinase $\mathrm{C}$
China and other northeast Asian countries. The crude plant extract of $D$. kaki is a very complex mixture containing compounds such as p-coumaric, gallic acid, catechin, flavonoids and tannin (1). The phytochemicals present in $D$. kaki have been used for therapeutic purposes such as scavenging of hypercholesterolemia, antioxidant and free radicals; detoxification of snake venom and toxic substances produced by microorganisms; and inhibition of human lymphoid leukemia cells (2). Vascorelaxant activity was also reported from D. kaki leaf extract (3). Major constituents of D. kaki leaves responsible for pharmacological effect are tannins, flavonoids/coumarins and terpenoids (1). Astragalin, a major constituent of flavonoids present in persimmon leaf extract, inhibited dermatitis development and IgE elevation in mice (4). Four flavonoids compound isolated from persimmon leaves inhibited angiotensin-converting enzyme activity in dose-dependent fashion (5). Similarly, five triterpenoids (6) and five flavonoids (7) compounds isolated from Diospyros kaki leaves have been reported to suppress stimulus-induced superoxide generation and tyrosyl phosphorylation in human neutrophils.

Most cancer cells are defective in their capacity to mature into non-replicating adult cells, thereby existing in a highly proliferating state and thus outgrowing their normal cellular counterparts. Leukaemia cells can be induced to undergo terminal differentiation by a variety of biochemical agents, indicating that the malignant state can be reversible. Leukemia may eventually prove treatable with agents that induce terminal differentiation, presumably with less morbidity than that associated with treatment with the cytodestructive agents (8). 1,25-dihydroxyvitamin $\mathrm{D}_{3}\left[1,25-(\mathrm{OH})_{2} \mathrm{D}_{3}\right]$ and all-trans retinoic acid (ATRA) are well known to be able to induce terminal differentiation in leukemic cell lines, such as HL-60 and U-937, as well as in short-term cultured acute promyelocytic leukemia (APL) cells in human $(9,10)$. However, an APL treatment by $1,25-(\mathrm{OH})_{2} \mathrm{D}_{3}$ and ATRA at a high dose results in side effects including acquisition of drug resistance and hypercalcemia. Therefore, the current approach in solving this problem involves the introduction of a second chemical which enhances the differentiation-inducing effects of 1,25$(\mathrm{OH})_{2} \mathrm{D}_{3}$ or ATRA at a lower, non-toxic concentration. HL-60 cells, extensively used as a model, differentiate into 
monocytic lineage when treated with $1,25-(\mathrm{OH})_{2} \mathrm{D}_{3}$ and into granulocytic lineage when treated with ATRA $(9,11)$, therefore this combination was selected for this study.

In the present study, we demonstrate that $D$. kaki leaf extract (KV-1) synergistically enhanced the differentiation potential of $1,25-(\mathrm{OH})_{2} \mathrm{D}_{3}$ or ATRA, which may be useful in acute promyelocytic leukemia (APL) therapy.

\section{Materials and methods}

Materials. Diospyros kaki Thunb. leaves were collected from Jeonnam area, in October 2006. The plants were authenticated by the Department of Pharmacognosy, Chosun University. First, 2 litres of acetone/water (80:20, v/v) solution was added to $1 \mathrm{~kg}$ wet leaves and left at room temperature. After 2 years, residue was removed by centrifugation and the resulting acetone-aqueous solution was evaporated with a rotary evaporator at $40^{\circ} \mathrm{C}$. The resulting thick residue was washed three times with hexane and then dissolved in dichloromethane before evaporation. The final residue, $\mathrm{KV}-1$ $(540 \mathrm{mg})$, was stored at $-20^{\circ} \mathrm{C}$ until use. $\mathrm{KV}-1$ was dissolved in dimethylsulfoxide (DMSO) to generate a $100 \mathrm{mg} / \mathrm{ml}$ stock solution. The solution was diluted at least 1,000-fold in the growth medium, such that the final DMSO concentration had no effect on the differentiation and proliferation behavior of the HL-60 cells. Manipulations were conducted under subdued light condition. The HL-60 cell line was obtained from American Type Culture Collection (ATCC, Rockville, MD, USA) and maintained in RPMI-1640 medium supplemented with $10 \%$ fetal bovine serum (Gibco BRL, Grand Island, NY, USA). 1,25-(OH) ${ }_{2} \mathrm{D}_{3}$, ATRA, phorbol 12-myristate 13-acetate (PMA), 2-[4-Morpholinyl]-8phenyl-1 [4H]-benzopyran-4-one (LY 294002), wortmannin, anthrapyrazolone (SP 600125), a Giemsa staining solution, methanol-free paraformaldehyde and all other reagents were purchased from Sigma Chemical Co. (St. Louis, MO, USA). Chelerythrine, 1-(5-isoquinolinesulfonyl)-2-methylpiperazine dihydrochloride (H 7) and 2-(2'-amino-3'-methoxyphenyl)oxanaphthalen-4-one (PD 98059) were purchased from Tocris Cookson Ltd. (UK). Stock solution of $1 \mathrm{mM}$ ATRA was dissolved in DMSO.

Determination of cell viability and differentiation. Cell viability was determined by the trypan blue exclusion assay, as previously described (12). Viability was calculated as the percentage of live cells in the total cell population. Cell differentiation was assessed by the nitroblue tetrazolium (NBT) reduction assay as previously described (13), which is based on the ability of phagocytic cells to produce superoxide upon stimulation with PMA. For the assay, cells were harvested by centrifugation at $3,000 \mathrm{x}$ g and incubated with an equal volume of $1 \%$ NBT dissolved in phosphate-buffered saline (PBS) containing $200 \mathrm{ng} / \mathrm{ml}$ of freshly diluted PMA at $37^{\circ} \mathrm{C}$ for $30 \mathrm{~min}$ in the dark. Cytospin slides were prepared and examined for a blue-black nitroblue diformazan deposit, indicative of a PMA-stimulated respiratory burst. At least 200 cells were assessed for each experiment.

Morphological studies. Single-cell suspensions were prepared and loaded into a cyto-funnel and spun at 1,050 x $\mathrm{g}$ in a cytospin centrifuge. The slides were fixed with methanol and dried. The slides were stained with a Giemsa staining solution for $20 \mathrm{~min}$ and rinsed in deionized water, air-dried and observed under a microscope with a camera. The stained cells were assessed for size, regularity of the cell margin and morphological characteristics of the nuclei.

Immunofluorescent staining and cytofluorometric measurements. The expression of cell surface molecules on cells was cytofluorometrically analyzed using a FACSCalibur flow cytometer (BD Bioscience, San Jose, CA). Briefly, a single-cell suspension was collected from each of the various cultures and washed twice with ice-cold PBS (pH 7.4). Afterwards, phycoerythrin (PE)-conjugated anti-human CD11b or fluorescein isothiocyanate (FITC)-conjugated anti-human CD14 mAbs (BD Bioscience) were added and incubated at $4^{\circ} \mathrm{C}$ for $1 \mathrm{~h}$. Next, the cells were washed with PBS and fixed in PBS containing $1 \%$ paraformaldehyde and then cytofluorometric analysis was performed. Background staining was determined by staining the cells with PE- or FITCconjugated isotype control mAbs. One parameter fluorescence histograms were generated by analyzing at least $1 \times 10^{4}$ cells.

Preparation of cell lysates and Western blot analysis. Cells were lysed by incubating in lysis buffer $(50 \mathrm{mM}$ Tris buffer, pH 7.5 containing $100 \mathrm{mM} \mathrm{NaCl}, 1 \%$ Nonidet P-40, $10 \%$ glycerol, $1 \mathrm{mM}$ EDTA, $1 \mathrm{mM} \mathrm{NaF}, 1 \mathrm{mM}$ sodium orthovanadate, $50 \mu \mathrm{g} / \mathrm{ml}$ leupeptin, $50 \mu \mathrm{g} / \mathrm{ml}$ aprotinin and $50 \mu \mathrm{g} / \mathrm{ml}$ phenylmethylsulphonyl fluoride) on ice for $30 \mathrm{~min}$. Lysates were then centrifuged at $13,000 \mathrm{x}$ g at $4^{\circ} \mathrm{C}$ for $10 \mathrm{~min}$. The proteins $(10 \mu \mathrm{g})$ of the supernatants were separated using a $10 \%$ sodium dodecyl sulfate-polyacrylamide gel (SDS-PAGE) and transferred to the nitrocellulose membrane. The blots were probed with rabbit anti-human PKC isoforms, mouse anti-pJNK, rabbit anti-JNK, mouse anti-pERK and rabbit anti-ERK2 antibodies, washed and exposed to horseradish peroxidase-conjugated anti-mouse $\operatorname{IgG} 2$ a or rabbit $\operatorname{IgG}$ antibodies. Immunoreactive bands were visualized by the enhanced chemiluminescence system (Amersham, Buckinghamshire, UK).

Statistical analysis. Student's t-test and one-way analysis of variance (ANOVA) followed by the Bonferroni method were used to determine the statistical significance of differences between the values of various experimental and control groups. A P-value of $<0.05$ was considered to be significant.

\section{Results}

Effect of $\mathrm{KV}-1$ on 1,25-(OH ${ }_{2} \mathrm{D}_{3^{-}}$and ATRA-induced HL-60 cell differentiation. The effect of an acetone extract of $D$. kaki leaves $(\mathrm{KV}-1)$ on $1,25-(\mathrm{OH})_{2} \mathrm{D}_{3}$ - or ATRA-induced HL-60 cell differentiation was examined. HL-60 leukemia cells were treated with $\mathrm{KV}-1$ in combination with either $1,25-(\mathrm{OH})_{2} \mathrm{D}_{3}$ or ATRA and cellular differentiation was assessed by NBT reduction assay. Cells treated with $\mathrm{KV}-1$ alone were taken as controls. Treatment with KV-1 alone induced a relatively small increase of HL-60 cell differentiation by $\sim 10 \%$, whereas the treatment with a suboptimal concentration of ATRA $(50 \mathrm{nM})$ or $1,25-(\mathrm{OH})_{2} \mathrm{D}_{3}(5 \mathrm{nM})$ resulted in a slight increase in the 
A

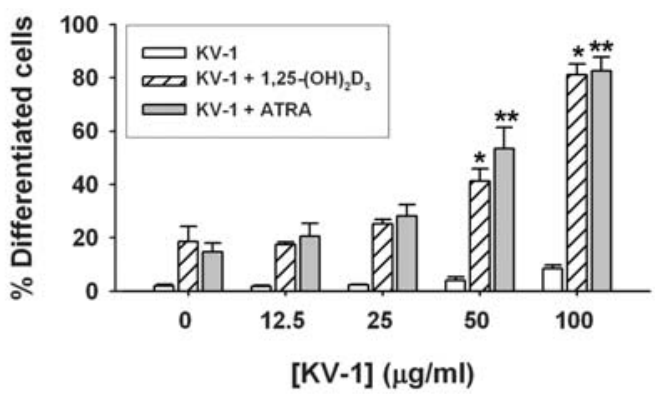

B

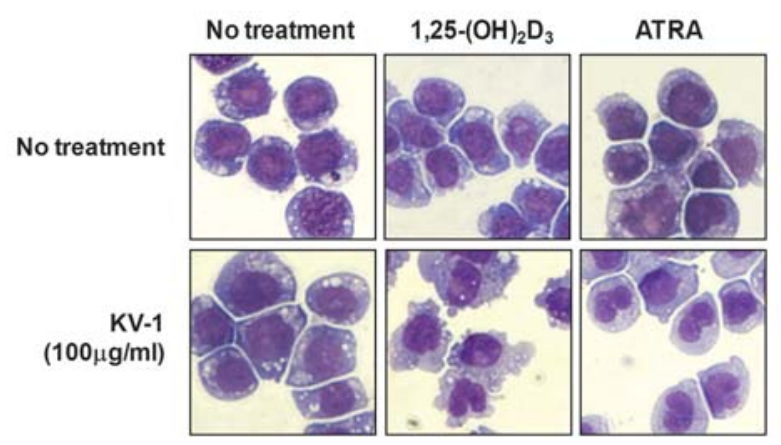

Figure 1. Effects of KV-1 on 1,25-(OH) $)_{2} \mathrm{D}_{3^{-}}$or ATRA-induced HL-60 cell differentiation. HL-60 cells were simultaneously treated with various

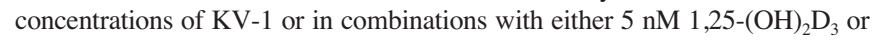
$50 \mathrm{nM}$ ATRA for $72 \mathrm{~h}$. (A) The cellular differentiation was assessed by the NBT reduction assay. Each value represents the mean \pm SEM $(n=3)$. ${ }^{*} \mathrm{P}<0.05$ relative to the $5 \mathrm{nM}$ of $1,25-(\mathrm{OH})_{2} \mathrm{D}_{3}$-treated group; ${ }^{* *} \mathrm{P}<0.05$ relative to the $50 \mathrm{nM}$ ATRA-treated group. (B) The treated HL-60 cells were assessed by morphological analysis using Giemsa stain.

degree of cell differentiation by $20 \%$ (Fig. 1A). Importantly, $\mathrm{KV}-1$ synergistically potentiated $1,25-(\mathrm{OH})_{2} \mathrm{D}_{3^{-}}$or ATRAinduced HL-60 cell differentiation. The effect of $5 \mathrm{nM} 1,25-$ $(\mathrm{OH})_{2} \mathrm{D}_{3}$ or $50 \mathrm{nM}$ ATRA in combination with $100 \mu \mathrm{g} / \mathrm{ml}$ KV-1 was considerably higher $(>80 \%)$ than the effect observed in the individual treatment $(<20 \%)$. For all treatment, cell viability was $>97 \%$ throughout the incubation period, as demonstrated by the trypan blue exclusion assay (data not shown).

Morphology of HL-60 cells was analyzed to further determine the cell differentiation enhanced by KV-1. Giemsastained undifferentiated control HL-60 cells (Fig. 1B) (upper left) were predominantly promyelocytes with round and regular cell margins and large nuclei, suggesting that the cells were highly active in DNA synthesis and were rapidly

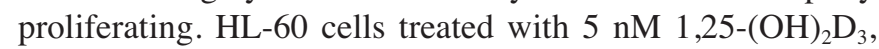
$50 \mathrm{nM}$ ATRA or $100 \mu \mathrm{g} / \mathrm{ml} \mathrm{KV-1}$ exhibited relatively small changes in cell morphology such as irregular cell margin. Combined treatment of HL-60 cells with $5 \mathrm{nM} 1,25-(\mathrm{OH})_{2} \mathrm{D}_{3}$ or $50 \mathrm{nM}$ ATRA plus $100 \mu \mathrm{g} / \mathrm{ml} \mathrm{KV-1} \mathrm{resulted} \mathrm{in} \mathrm{a} \mathrm{signifi-}$ cantly decreased cell size, denser chromatin and increased cytoplasm to nuclear ratio, indicating the differentiation of HL-60 cells. Some cells showed a multilobed nucleus (Fig. 1B), which is also a mark of cell differentiation.

Effects of $\mathrm{KV}-1$ and 1,25-(OH $)_{2} \mathrm{D}_{3}$ or ATRA on differentiation pathways of HL-60 cells. Cytofluorometric analysis was performed to determine the expression of specific surface antigens on HL-60 cells. HL-60 leukemia cells express a cell surface marker, CD11b, when the cells are differentiated into monocytes and granulocytes (14). Treatment with KV-1 markedly increased the number of cells with high fluorescence intensity and also synergistically increased the number of the CD11b-positive cells when combined with either $5 \mathrm{nM}$ $1,25-(\mathrm{OH})_{2} \mathrm{D}_{3}$ or $50 \mathrm{nM}$ ATRA, confirming that $\mathrm{KV}-1$ potentiated 1,25-(OH) ${ }_{2} \mathrm{D}_{3^{-}}$or ATRA-induced HL-60 cell differentiation (Fig. 2A).

To determine the differentiation pathway following treatment with KV-1 and ATRA or $1,25-(\mathrm{OH})_{2} \mathrm{D}_{3}$, the expression of CD14 antigen was cytofluorometrically analyzed on the treated HL-60 cells with $\mathrm{KV}-1$ alone or in combination with either $1,25-(\mathrm{OH})_{2} \mathrm{D}_{3}$ or ATRA. The CD14 antigen is exclusively expressed when cells are differentiated into monocytes (15). HL-60 cells treated with a mixture of $\mathrm{KV}-1$ and $1,25-(\mathrm{OH})_{2} \mathrm{D}_{3}$ reacted very strongly with anti-CD14 $\mathrm{mAb}$ (Fig. 2B). Cells treated with $1,25-(\mathrm{OH})_{2} \mathrm{D}_{3}$ alone also reacted with the anti-CD14 mAb, but to a lesser extent than did the cells treated with a mixture of KV-1 and $1,25-(\mathrm{OH})_{2} \mathrm{D}_{3}$. These results indicate that $\mathrm{KV}-1$ stimulated $1,25-(\mathrm{OH})_{2} \mathrm{D}_{3^{-}}$ induced HL-60 cell differentiation along the monocytic pathway. In contrast, HL-60 cells treated with a mixture of KV-1 and ATRA showed little staining with anti-CD14 mAb, although synergistic induction of cell differentiation was observed, as shown by NBT reduction assay. Alternatively, the HL-60 cell treated with a mixture of KV-1 and ATRA stained strongly with a monoclonal antibody against HL-60 cell differentiation marker CD11b (Fig. 2A), indicating that KV-1 stimulated ATRA induced HL-60 cell differentiation along the granulocytic pathway.

Involvement of PKC and ERK in the HL-60 cell differentiation induced by $K V-1$ in combination with 1,25- $(\mathrm{OH})_{2} \mathrm{D}_{3}$ or ATRA. To determine if any relationship existed between the effect of $\mathrm{KV}-1$ on $1,25-(\mathrm{OH})_{2} \mathrm{D}_{3}$ - or ATRA-induced cell differentiation and activation of specific kinases involved in signaling pathways, the HL-60 cells were pretreated with each of specific inhibitors and incubated for $72 \mathrm{~h}$ in the presence of $\mathrm{KV}-1$ alone or in combination with either $1,25-(\mathrm{OH})_{2} \mathrm{D}_{3}$ or ATRA. Afterward, the degree of cell differentiation was assessed by an NBT reduction assay. The PI3-K inhibitors (wortmannin and LY 294002) and JNK inhibitor (SP 600125) did not inhibit HL-60 cell differentiation induced by $\mathrm{KV}-1$ in combination with 1,25-(OH) $)_{2} \mathrm{D}_{3}$ or ATRA (Fig. 3). In contrast, the PKC inhibitors (GF 102903X, chelerythrine, H7 and PKC peptide inhibitor) (Fig. 4A) and ERK inhibitor (PD 98059) (Fig. 5A) notably suppressed the HL-60 cell differentiation treated with $\mathrm{KV}-1$ in combination with $1,25-(\mathrm{OH})_{2} \mathrm{D}_{3}$ or ATRA.

To further investigate the involvement of PKC in HL-60 cell differentiation enhanced by KV-1, the HL-60 cells were treated with $100 \mu \mathrm{g} / \mathrm{ml} \mathrm{KV-1}$ and the protein levels of PKC isoforms were determined by Western blot analysis using $\mathrm{mAbs}$ for each PKC isoform. In this study, we focused on the conventional PKC isoforms such as $\alpha, \beta \mathrm{I}, \beta \mathrm{II}$, as these PKC isoforms are known to be the most abundantly expressed in leukemia cells and the expression levels have been correlated closely with cell differentiation in HL-60 cells (16). KV-1 increased protein levels of total PKC; in particular, $\mathrm{KV}-1$ increased protein level of PKC $\alpha$ and PKC ßI, but not that of 
A
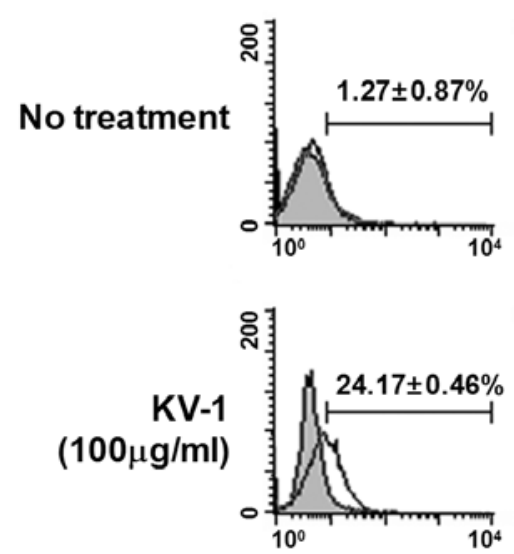

$1,25-(\mathrm{OH})_{2} \mathrm{D}_{3}$
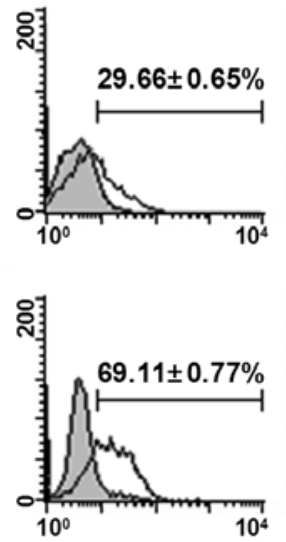

$1,25-(\mathrm{OH})_{2} \mathrm{D}_{3}$
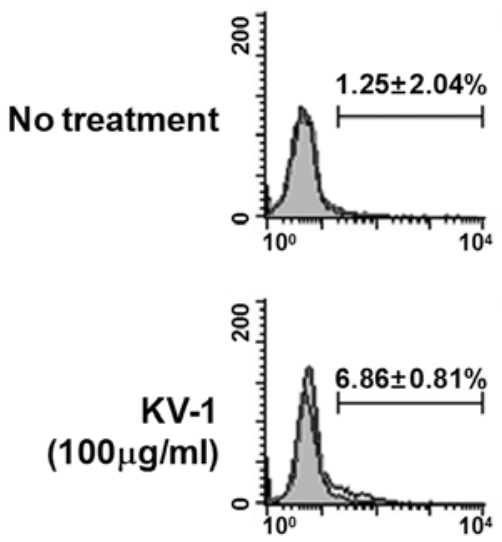
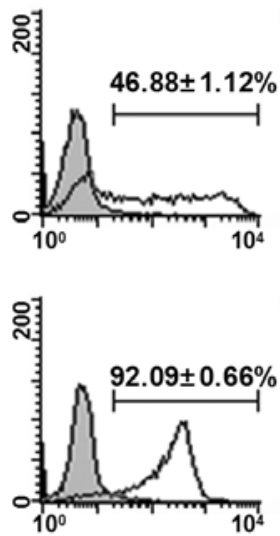

ATRA
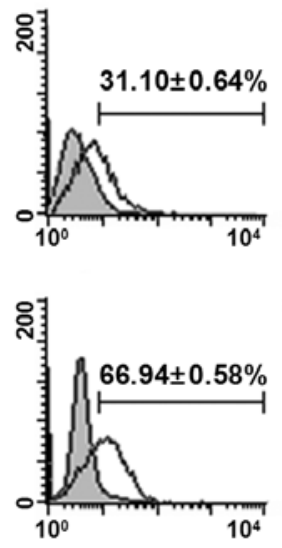
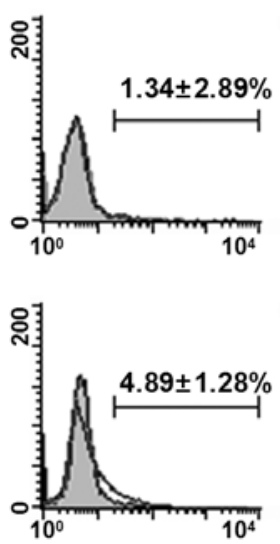

Figure 2. Cytofluorometric analysis of HL-60 leukemia cells treated with KV-1. HL-60 cells were treated for $72 \mathrm{~h}$ with $100 \mu \mathrm{g} / \mathrm{ml}$ of $\mathrm{KV}-1$ in combination with either $5 \mathrm{nM} 1,25-(\mathrm{OH})_{2} \mathrm{D}_{3}$ or $50 \mathrm{nM}$ ATRA. The cells were assessed by cytofluorometric analysis using (A) PE-conjugated anti-CD11b mAb or (B) FITC-conjugated anti-CD14 mAb (unshaded area), or each isotype control mAb (shaded area). The data are representative of three independent experiments.
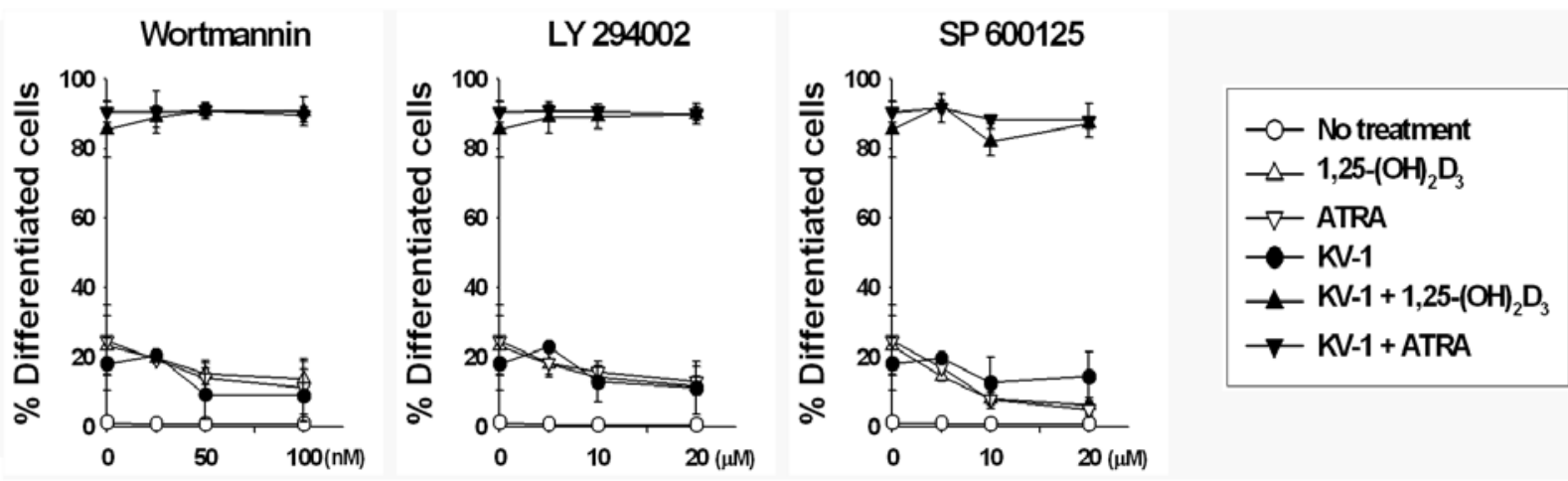

Figure 3. No involvement of PI3-K and JNK in HL-60 cell differentiation induced by KV-1 in combination with $1,25-(\mathrm{OH})_{2} \mathrm{D}_{3}$ or ATRA. HL-60 cells were treated with various concentrations of PI3-K inhibitors (wortmannin and LY 294002) or JNK inhibitor (SP 600125) for $1 \mathrm{~h}$, followed by incubating with $100 \mu \mathrm{g} / \mathrm{ml}$

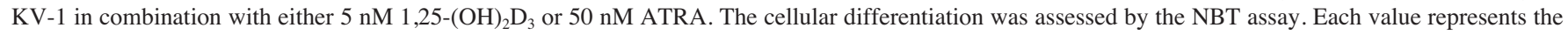
mean $\pm \operatorname{SEM}(n=3)$.

PKC BII (Fig. 4B). To further elucidate the involvement of ERK, the protein levels of ERK was determined by Western blot analysis. The levels of pERK increased by the treatment with $\mathrm{KV}-1$ alone and $\mathrm{KV}-1$ plus ATRA or $1,25-(\mathrm{OH})_{2} \mathrm{D}_{3}$ (Fig. 5B).

\section{Discussion}

In the present study, we demonstrated that KV-1 enhanced $1,25-(\mathrm{OH})_{2} \mathrm{D}_{3^{-}}$and ATRA-induced differentiation in HL-60 leukemia cells, which are widely used as a model system for 
A

$-O$ No treatment
$-\triangle 1,25-(\mathrm{OH})_{2} \mathrm{D}_{3}$
$\square-\mathrm{ATRA}$
$-\mathrm{KV}-1$
$-\mathrm{KV}-1+1,25-(\mathrm{OH})_{2} \mathrm{D}_{3}$
$\square \mathrm{KV}-1+\mathrm{ATRA}$

Chelerythrine

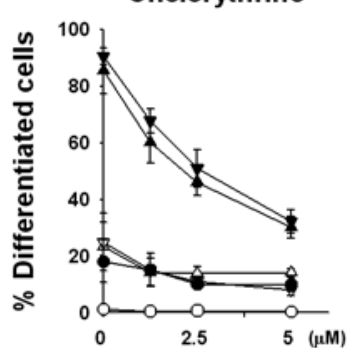

H 7

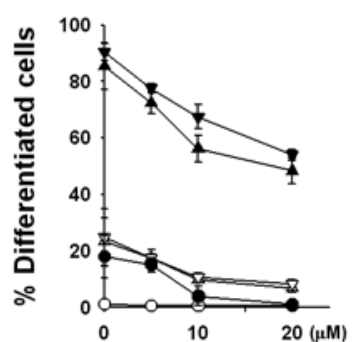

GF 109203X

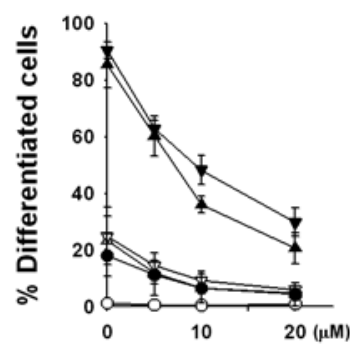

PKC inhibitor

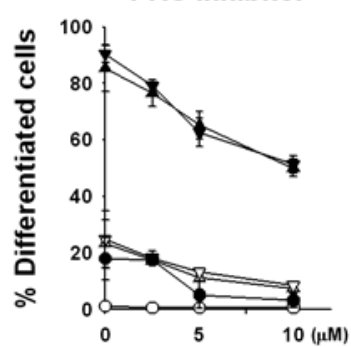

B

$\begin{array}{rllllll}\mathrm{KV}-1 & - & + & - & + & - & + \\ 1,25-(\mathrm{OH})_{2} \mathrm{D}_{3} & - & - & + & + & - & - \\ \text { ATRA } & - & - & - & - & + & +\end{array}$
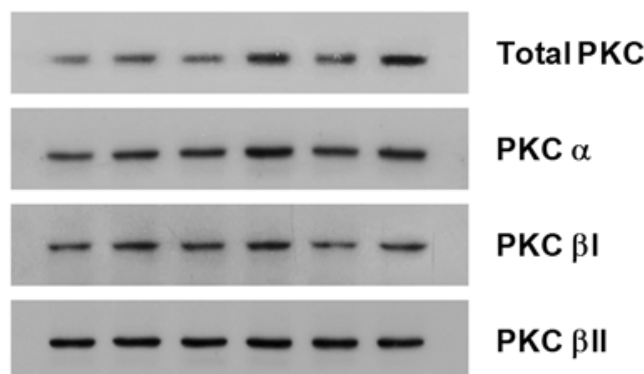

---- GAPDH

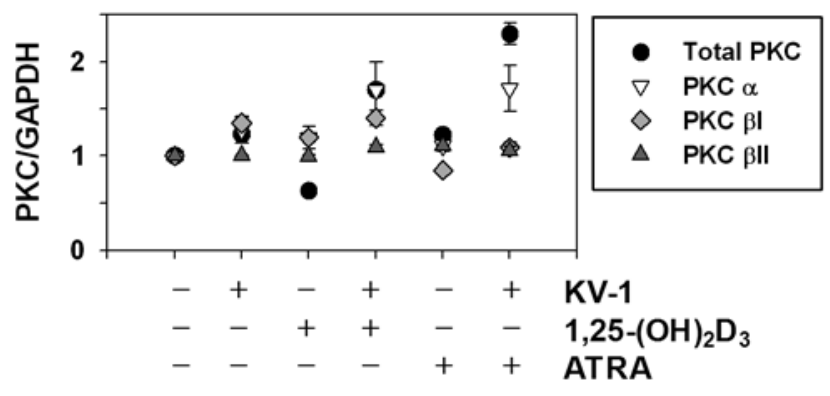

Figure 4. Involvement of PKC in HL-60 cell differentiation induced by KV-1 in combination with 1,25-(OH $)_{2} \mathrm{D}_{3}$ or ATRA. (A) HL-60 cells were treated with various concentrations of PKC inhibitors (GF 102903X, chelerythrine, H7 and PKC peptide inhibitor) for $1 \mathrm{~h}$, followed by incubation with $100 \mu \mathrm{g} / \mathrm{ml} \mathrm{KV-1} \mathrm{in}$ combination with either $5 \mathrm{nM} 1,25-(\mathrm{OH})_{2} \mathrm{D}_{3}$ or $50 \mathrm{nM}$ ATRA. The cellular differentiation was assessed by the NBT assay. Each value represents the mean $\pm \mathrm{SEM}$ (n=3). (B) HL-60 cells were treated with $100 \mu \mathrm{g} / \mathrm{ml} \mathrm{KV-1}$ alone or in combination with either $5 \mathrm{nM} 1,25-(\mathrm{OH})_{2} \mathrm{D}_{3}$ or $50 \mathrm{nM}$ ATRA for $1 \mathrm{~h}$. The protein level of total PKC and each of conventional PKC isoforms were determined by Western blot analysis. The experiment was repeated twice with similar results.

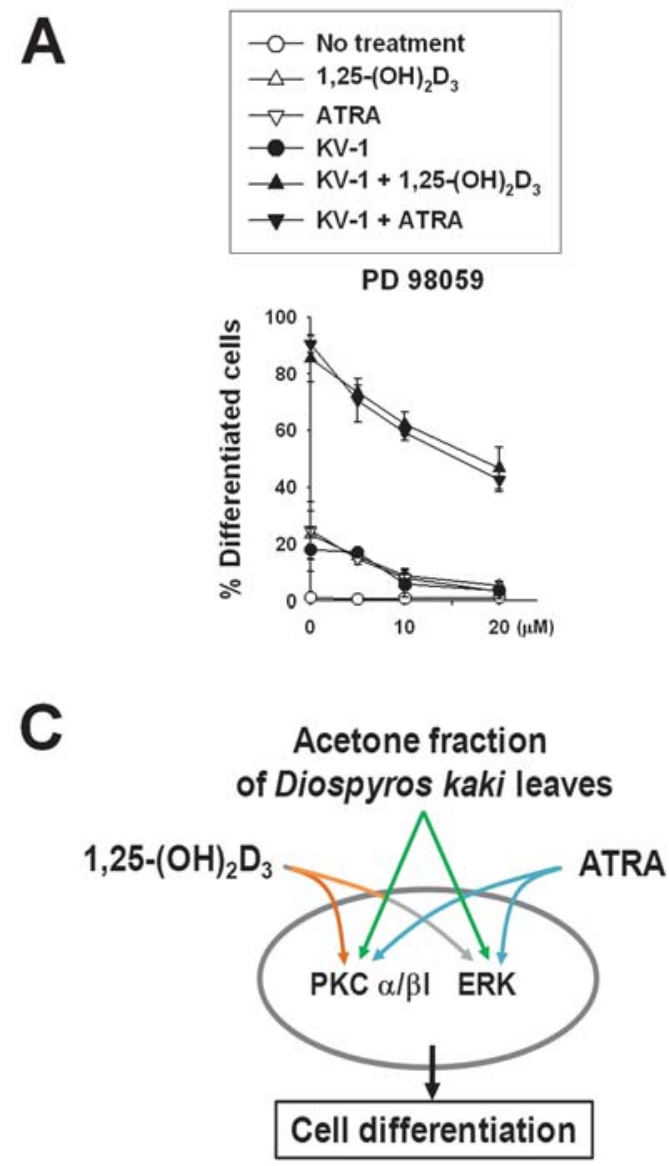

B

$\begin{array}{rllllll}\mathrm{KV}-1 & - & + & - & + & - & + \\ 1,25-(\mathrm{OH})_{2} \mathrm{D}_{3} & - & - & + & + & - & - \\ \text { ATRA } & - & - & - & - & + & +\end{array}$

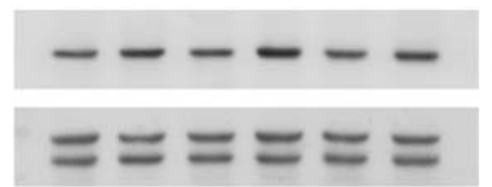

pERK

ERK

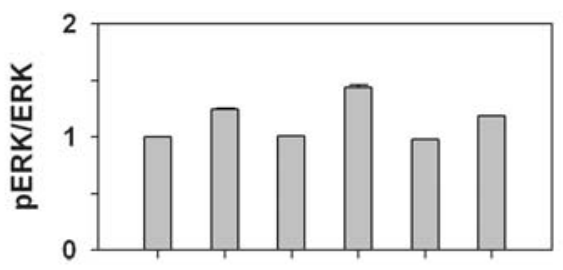

Figure 5. Involvement of ERK and a proposed action mechanism in KV-1mediated enhancement of HL-60 cell differentiation. (A) HL-60 cells were treated with various concentrations of ERK inhibitor (PD 98059) for $1 \mathrm{~h}$, followed by incubation with $100 \mu \mathrm{g} / \mathrm{ml} \mathrm{KV}-1$ in combination with either $5 \mathrm{nM}$ $1,25-(\mathrm{OH})_{2} \mathrm{D}_{3}$ or $50 \mathrm{nM}$ ATRA. The cellular differentiation was assessed by the NBT assay. Each value represents the mean \pm SEM $(n=3)$. (B) HL-60 cells were treated with $100 \mu \mathrm{g} / \mathrm{ml} \mathrm{KV-1}$ alone or in combination with either $5 \mathrm{nM}$ $1,25-(\mathrm{OH})_{2} \mathrm{D}_{3}$ or $50 \mathrm{nM}$ ATRA for $1 \mathrm{~h}$. The protein level of ERK and phoERK were determined by Western blot analysis. The experiment was repeated twice with similar results. (C) A proposed mechanism of the KV-1-treated HL-60 cell differentiation in combination with $1,25-(\mathrm{OH})_{2} \mathrm{D}_{3}$ or ATRA. 
studies of differentiation. HL-60 cells were synergistically differentiated into monocytes and granulocytes when treated with KV-1 in combination with a low dose of $1,25-(\mathrm{OH})_{2} \mathrm{D}_{3}$ and ATRA, respectively. ATRA combinations with histone deacetylase inhibitors (17) and gefitinib (18) exerted synergistic effects on HL-60 cell differentiation. Similarly, ascorbate (19), capsaicin (20) and cyclooxygenase inhibitors (21) enhanced the HL-60 cell differentiation produced by a low level of $1,25-(\mathrm{OH})_{2} \mathrm{D}_{3}$.

Previous studies have revealed that PKC activation is necessary for the differentiation of HL-60 cells $(16,22)$ and mitogen-activated protein kinases (MAPKs) are downstream elements in the PKC signaling pathway of HL-60 cells (23). The c-Jun N-terminal kinase (JNK) signaling module is also known to participate in myeloid cell differentiation $(24,25)$. Phosphatidylinositol 3-kinase (PI3-K) activity plays an essential role in differentiation of HL-60 cells (26). Here, a combination of $\mathrm{KV}-1$ with $1,25-(\mathrm{OH})_{2} \mathrm{D}_{3}$ or ATRA contributed to the activation of the PKC and ERK, but not that of PI3-K or JNK-mediated pathways, as demonstrated by Western blot analyses and kinase inhibitor studies, although protein levels of the conventional PKC isoforms $\alpha$ and $\beta I$ increased at different extent (Figs. 3-5). Taken together, the results suggest that $\mathrm{KV}-1$ potentiates ATRA- and 1,25- $(\mathrm{OH})_{2} \mathrm{D}_{3}$ induced HL-60 cell differentiation through distinct pathways through $\mathrm{PKC}(\alpha, \beta \mathrm{I}) / \mathrm{ERK}$ without involvement of PI3-K and JNK (Fig. 5C). Recently, we have shown that a methanol extract of Panax ginseng synergistically induced differentiation potential of ATRA and $1,25-(\mathrm{OH})_{2} \mathrm{D}_{3}$ with the involvement of PKC/ERK, but not that of PI3-K (27).

Phytochemicals present in D. kaki have several pharmacological effects including potential inhibitory effects on human lymphoid leukemia cells (1-4). Major constituents of $D$. kaki leaves responsible for pharmacological effect are flavonoids and terpenoids $(1,4-7)$. Therefore, although we could not pinpoint the exact active compound present in acetone extract of $\mathrm{KV}$-1, flavonoid and/or terpenoid compound might be responsible for ATRA and $1,25-(\mathrm{OH})_{2} \mathrm{D}_{3}$-induced HL-60 differentiation. Epidemiological studies suggest that there is a low risk of many kinds of cancer to the people who eat large amounts of fruits and vegetables (28). Although the underlying reason is largely unclear, various dietary chemicals such as curcuminoids, and carotenoids may possibly prevent human cancer in part by synergizing endogenously produced differentiation stimulators such as retinoic acids and 1,25$(\mathrm{OH})_{2} \mathrm{D}_{3}$.

In summary, an acetone extract of $D$. kaki leaves markedly increased the HL-60 cell differentiation in combination of a low dose of $1,25-(\mathrm{OH})_{2} \mathrm{D}_{3}$ or ATRA via PKC $(\alpha, \beta \mathrm{I}) / \mathrm{ERK}$ pathways. The results suggest that treatment of acute promyelocytic leukemia patients with combinations of acetone extract of $D$. kaki leaves and ATRA or $1,25-(\mathrm{OH})_{2} \mathrm{D}_{3}$ may provide a greater therapeutic response than $1,25-(\mathrm{OH})_{2} \mathrm{D}_{3}$ or ATRA alone.

\section{References}

1. Mallavadhani UV, Panda AK and Rao YR: Pharmacology and chemotaxonomy of Diospyros. Photochemistry 49: 901-951, 1998 .
2. Gu H, Li C, Xu Y, Hu W, Chen M and Wan Q: Structural features and antioxidant activity of tannin from persimmon pulp. Food Res Int 41: 208-217, 2008.

3. Yin MH, Kang DG, Choi DH, Kwon TO and Lee HS: Screening of vascorelaxant activity of some medicinal plants used in Oriental medicines. J Ethnopharmacol 99: 113-117, 2005.

4. Kotani M, Matsumoto M, Fujita A, Higa S, Wang W, Suemura M, Kishimoto T and Tanaka T: Persimmon leaf extract and astragalin inhibit development of dermatitis and IgE elevation in NC/Nga mice. J Allergy Clin Immun 106: 159-166, 2002.

5. Kameda K, Takaku T, Okuda H, et al: Inhibitory effects of various favonoids isolated from leaves of persimmon on angiotensinconverting enzyme activity. J Nat Prod 50: 680-683, 1987.

6. Chen G, Lu H, Wang C, Yamashita K, Manabe M, Xu S and Kodama H: Effect of five triterpenoid compounds isolated from leaves of Diospyros kaki on stimulus-induced superoxide generation and tyrosyl phosphorylation in human polymorphonuclear leukocytes. Clin Chim Acta 320: 11-16, 2002.

7. Chen G, Lu H, Wang C, Yamashita K, Manabe M, Meng Z, Xu S and Kodama H: Effect of five flavonoid compounds isolated from leaves of Diospyros kaki on stimulus-induced superoxide generation and tyrosyl phosphorylation of proteins in human neutrophils. Clin Chim Acta 326: 169-175, 2002.

8. Beere HM and Hickman JA: Differentiation: a suitable strategy for cancer chemotherapy? Anticancer Drug Des 8: 299-322, 1993.

9. Breitman TR, Selonick SE and Collins SJ: Induction of differentiation of the human promyelocytic leukemia cell line (HL-60) by retinoic acid. Proc Natl Acad Sci USA 77: 2936-2940, 1980.

10. Chomienne C, Balitrand N, Cost H, Degos L and Abita JP: Structure-activity relationships of aromatic retinoids on the differentiation of the human histiocytic lymphoma cell line U-937. Leuk Res 10: 1301-1305, 1986.

11. Tanaka H, Abe E, Miyaura C, Shiina Y and Suda T: 1 alpha,25ihydroxyvitamin $\mathrm{D}_{3}$ induces differentiation of human promyelocytic leukemia cells (HL-60) into monocyte-macrophages, but not into granulocytes. Biochem Biophys Res Commun 117: 86-92, 1983

12. Coligan JE, Kruisbeck AM, Margulies DH, Shevach EM and Strober W: Current Protocols in Immunology. J Wiley, New York, 1995.

13. Collins SJ, Ruscetti FW, Gallagher RE and Gallo RC: Normal functional characteristics of cultured human promyelocytic leukemia cells (HL-60) after induction of differentiation by dimethylsulfoxide. J Exp Med 149: 969-974, 1979.

14. Kansas GS, Muirhead MJ and Dailey MO: Expression of the CD11/CD18, leukocyte adhesion molecule 1, and CD44 adhesion molecules during normal myeloid and erythroid differentiation in humans. Blood 6: 2483-2492, 1990.

15. Wright SD, Ramos RA, Tobias PS, Ulevitch RJ and Mathison JC: CD14, a receptor for complexes of lipopolysaccharide (LPS) and LPS binding protein. Science 249: 1431-1433, 1990.

16. Wu XZ, Shao GY, Chen S, Wang XW and Wang ZY: Studies on the relationship between protein kinase $\mathrm{C}$ and differentiation of human promyelocytic leukemia cells induced by retinoic acid. Leuk Res 13: 869-874, 1989.

17. Savickiene J, Treigyte G, Borutinskaite V, Navakauskiene R and Magnusson KE: The histone deacetylase inhibitor FK228 distinctly sensitizes the human leukemia cells to retinoic acidinduced differentiation. Ann NY Acad Sci 1091: 368-384, 2006.

18. Miranda MB, Duan R, Thomas SM, Grandis JR, Redner RL, Jones JE and Johnson DE: Gefitinib potentiates myeloid cell differentiation by ATRA. Leukemia 22: 1624-1627, 2008.

19. Lopez-Lluch G, Fernandez-Ayala DJ, Alcaín FJ, Burón MI, Quesada JM and Navas P: Inhibition of COX activity by NSAIDs or ascorbate increases cAMP levels and enhances differentiation in 1alpha,25-dihydroxyvitamin $\mathrm{D}_{3}$-induced HL-60 cells. Arch Biochem Biophys 436: 32-39, 2005.

20. Kang SN, Chung SW and Kim TS: Capsaicin potentiates 1,25dihydroxyvitamin $\mathrm{D}_{3^{-}}$and all-trans retinoic acid-induced differentiation of human promyelocytic leukemia HL-60 cells. Eur J Pharmacol 420: 83-90, 2001.

21. Jamshidi F, Zhang J, Harrison JS, Wang X and Studzinski GP: Induction of differentiation of human leukemia cells by combinations of COX inhibitors and 1,25-dihydroxyvitamin D3 involves Raf1 but not Erk 1/2 signaling. Cell Cycle 7: 917-924, 2008.

22. Li Q, Ozer H, Lindner I, Lee KP and Kharfan-Dabaja MA: Protein kinase $\mathrm{C}$ blockade inhibits differentiation of myeloid blasts into dendritic cells by calcium ionophore A23187. Int J Hematol 81: 131-137, 2005. 
23. Studzinski GP, Garay E, Patel R, Zhang J and Wang X: Vitamin D receptor signaling of monocytic differentiation in human leukemia cells: role of MAPK pathways in transcription factor activation. Curr Top Med Chem 6: 1267-1271, 2006.

24. Wang Q, Wang X and Studzinski GP: Jun N-terminal kinase pathway enhances signaling of monocytic differentiation of human leukemia cells induced by 1,25-dihydroxyvitamin $\mathrm{D}_{3}$. J Cell Biochem 89: 1087-1101, 2003.

25. Mathieu J and Besancon F: Arsenic trioxide represses NFkappaB activation and increases apoptosis in ATRA-treated APL cells. Ann NY Acad Sci 1090: 203-208, 2006.

26. Bertagnolo V, Neri LM, Marchisio M, Mischiati C and Capitani S: Phosphoinositide 3-kinase activity is essential for all-transretinoic acid-induced granulocytic differentiation of HL-60 cells. Cancer Res 59: 542-546, 1999.
27. Kim SH, Cho SS, Simkhada JR, Lee JH, Kim SW, Kim TS and Yoo JC: Enhancement of 1,25-dihydorxyvitamin $\mathrm{D}_{3}$-and all-trans retinoic acid-induced HL-60 leukemia cell differentiation by Panax ginseng. Biosci Biotechnol Biochem 73: 1048-1053, 2009.

28. Powolny AA and Singh SV: Multitargeted prevention and therapy of cancer by diallyl trisulfide and related Allium vegetable-derived organosulfur compounds. Cancer Lett 269: 305-314, 2008. 